\title{
DISABILITY AND WELFARE
}

Writing to The Times in the aftermath of the Gethin Colliery explosion of 1865 , Dr W. Wadham wrote movingly on behalf of the victims of the tragedy - 'for those who are dead, for those who linger in their agony' and 'for the widows and orphans of the first, and the aged and little ones depending for their daily bread upon the now no longer available labour of the latter'. These were people, he wrote, who deserved not philanthropy, but better measures to ensure safety in coal mines. Victims of disasters required no 'alms', he wrote, 'feeling that by mutual assistance, and that heroic self-dependence so happily distinguishing the mining population of Wales, they will know how to encounter and overcome the pecuniary distresses accompanying a catastrophe which would render those less strong of heart the recipients of public charity'. ${ }^{1}$ Just over a decade later, a similar view was presented in the Glasgow Herald of Scottish coal workers. 'All who know the decent working people of this part of the kingdom', the article contended, 'are aware how reluctant they are, as a rule, to become ... the recipients of charity.' It extolled the virtues of the careful, self-sufficient miner whose infirmity was supported by payments from the 'box' of his friendly society, into which he had contributed 'when able to work'. Such a man was 'regarded as a gentleman compared with one who has had to go on the parish'. ${ }^{2}$ Contrasting with the stereotype of miners as feckless, the image of the self-sufficient coal worker, managing his own welfare needs or supported by mutual aid in his community, was a powerful ideal and motivated thousands of miners to join friendly societies, insurance schemes, pit clubs and trade unions as the nineteenth century progressed. ${ }^{3}$

Disability has long been at the heart of discussions and debates about welfare. It has been used as a yardstick by policymakers, charities and self-help organisations to determine not only who needs support and assistance, but also who deserves it. ${ }^{4}$ Welfare systems played a critical role in defining 'disability' 
during our period and also imposed a series of responsibilities and moral strictures on those who sought support. At the same time, those claiming relief had their own ideas about the help to which they felt entitled, and these expectations also shaped their experiences. Although material support or assistance was often crucial in maintaining the economic well-being of individuals and their families, welfare, as the examples above show, was an emotional issue that evoked feelings of pity, pride, dependency, hostility and responsibility. These feelings, as much as the practicalities of financial or medical provision, shaped experiences of welfare in the past, as they continue to do so today.

As the previous chapter suggested, coalminers, like other nineteenthcentury workers, were enmeshed in a 'mixed economy' of welfare that comprised many sources of assistance - from family support to self-help initiatives. It also included public charity and support from the state through the Poor Law, despite the image of the heroically 'self-dependant' worker commonly propagated by the labour movement. Due to the high rate of non-fatal accidents and industrial diseases in the sector, mining developed its own distinct ecosystem of welfare, designed to meet the specific needs of disabled coalminers. The sick clubs established by paternalist coal owners, explored in the previous chapter, were part of this, but so too were initiatives devised and promoted by miners themselves. As we shall see, the friendly societies lauded by the author of the article in the Glasgow Herald were not always welcoming of coalminers, particularly at the beginning of our period. Frustration with the ability of funds to cater for the needs of the long-term disabled led to new initiatives to form distinctive, occupationally focused forms of self-help, of which the most notable was the permanent relief fund movement founded in the wake of the Hartley Colliery disaster of $1862 .{ }^{5}$

Focusing on the general (non-medical) support available to sick, injured and impaired mineworkers, and the social and cultural principles that underpinned it, this chapter explores where disabled miners and their families stood within the matrix of welfare expectations and provisions, and how this affected their ability to secure assistance in times of need. Where did responsibility for the care and support of ill and injured mineworkers reside and what type of assistance was given? What, moreover, were the expectations of welfare claimants and providers in coalfield communities? And how did these expectations shape the experiences of disabled miners? To answer these questions, this chapter examines mineworkers' experiences of the different strands - domestic, public and voluntary - that constituted the patchwork of care and assistance available to them. While the chapter examines each of these dimensions of welfare in turn, it is important to recognise their interdependence. Individuals often drew on different forms of support simultane- 
ously. Sixty-three-year-old former hewer Robert Young, for example, revealed the delicate web of welfare supporting him to the Children's Employment Commission in the early 1840s. No longer able to work at mining after losing his leg at a Scottish coal works seven years previously, Young was getting by with a patchwork of assistance. Mr Deans, the owner of nearby Penston Colliery in East Lothian, allowed him free housing and coal. On top of this, however, Young also relied on small weekly poor relief payments from his local parish and the occasional shilling he and his wife managed to earn 'nursing the bairns of the wives who work below' ${ }^{6}$ Other disabled mineworkers similarly drew on various combinations of help from different sources of assistance, as one alone was rarely ever sufficient to make ends meet. This chapter examines how mineworkers utilised these differing support mechanisms and brought them together to fashion a successful survival strategy for themselves and their families.

\section{Domestic sites and sources of welfare}

As we saw in the previous chapter, for most sick or injured miners, the primary location of care was the home. The home also occupied a central position in nineteenth-century welfare practices. Despite a growth in institutions aimed at tackling poverty, Britons in need were most often helped in domestic, not institutional, settings during the period. Eighteenth- and nineteenth-century Britons were under a moral obligation to support any incapacitated members of their families. Parents, children and even grandparents were expected to help relatives if they were in a position to do so, and most did. ${ }^{7}$ Indeed, of all working-class communities, those centred on mining were thought by some Victorians to have had a particularly good record in this regard. In the mid-nineteenth century, one keen observer, at least, noted that 'Old pitmen' in north-east England were 'very generally supported in whole or in part by their grown-up families - a filial duty, the performance of which is far more common in the mining than in the manufacturing districts'. ${ }^{8}$

In principle, male heads of households were ultimately responsible for the welfare of everyone in their families, but women and children also made important contributions. As we have seen, prior to 1842 , women, girls and young children had been permitted to work underground in mines, and several thousand did, especially in Scottish coal mines (around 40 per cent of the total workforce). ${ }^{9}$ Their work provided a means of protecting households against falling into poverty and becoming reliant on poor relief. Church has estimated that about one-third of females interviewed by the 1842 Children's Employment Commission reported having dead or disabled fathers. ${ }^{10}$ Their 
labour generated valuable income for the support of their families, perhaps contributing one-quarter to half of a Scottish mining household's income where all members worked. ${ }^{11}$ Some women worked underground to support their incapacitated husbands. For example, Margaret Boxter (or Baxter), aged fifty, of Bathgate, one of the few women who worked at hewing rather than hauling coal, said that she had worked underground for twelve years, ever since her husband 'failed in his breath' and was incapacitated from working himself. ${ }^{12}$

Even in areas where women were not employed underground, as in the north-east of England, sending very young children to work in coal mines was a familiar survival strategy for mining families struggling to cope with the effects of disability or other family misfortune. Ann Mills testified that she had sent her son Matthew to work underground to open and close the doors used to ventilate Blaydon Main Colliery at the tender age of six 'on account of her husband's bad breath'. ${ }^{13}$ According to Robert Franks in his report on the east of Scotland for the 1842 Children's Employment Commission, child labour in the mines was a symptom of the inadequacies of the 'Scotch system of poor law', which forced 'youthful labour into the pits at an early age, in order to raise support for indigent parents who received either inefficient relief, or no relief at all, from the parish' - although a desire to avoid parochial relief may have been just as important for some. ${ }^{14}$ Time and again, young witnesses reported that their employment underground was motivated by the necessity of contributing to the family economy. Thus William Naysmith, a twelve-yearold Scottish putter testified that he came to work underground 'as it would be more benefit to my father, who is off work with bad breath. Father, mother and five other children depend on the labour of brother and myself. ${ }^{15}$ Injury or chronic illness seems to have forced some miners to rush their children into the mines earlier than planned. Twelve-year-old mineworker Robert Dickson, for example, reported that 'Father would not have sent me below so soon had he not been bad in the breath. ${ }^{16}$ While some proprietors of coal mines testified that they were unwilling to allow very young children to work underground, they said that exceptions were made for 'children of widows, or where the families are very large.'. ${ }^{17}$

Although the 1842 Mines and Collieries Act's prohibition of the employment of all females and boys under the age of ten was hailed as preventing a great social evil, the legislation was a mixed blessing for families of disabled mineworkers. On the one hand, in banning women's work underground, the act intended to promote a 'domestic ideology' that emphasised the role of women as carers and nurturers within their families. The law had considerable success in this area and many discharged female coal workers did indeed end 
up in the home, as reformers had hoped. This may have represented a welfare boon of sorts for mining families, since they no longer had to pay women from outside their households to perform domestic tasks for them, as many had done prior to the 1842 Act when hard working mining wives and daughters were simply too tired and lacked the time to 'keep house' properly. ${ }^{18}$ For disabled miners who required care, then, the increased presence of female relatives at home after 1842 may have offered an element of emotional comfort and support not available from non-relatives.

On the other hand, the legislation robbed families of disabled mineworkers of an important source of income. ${ }^{19}$ In 1845, for example, only about 200 Scottish pit women out of those thrown out of work by the law had new jobs. ${ }^{20}$ Some mining families with disabled members may have fared even worse from the operation of the Mines and Collieries Act, especially if they lived in company housing at the time the law was passed. Speaking in the House of Commons in May 1843, Renfrewshire MP Patrick Stewart drew his fellow parliamentarians' attention to the possible implications of the act to the welfare of mining families. Referring to a practice common in Scotland whereby disabled miners were allowed to keep their company houses providing someone in their household continued to work for the mine, Stewart raised the possibility that disabled colliers supported entirely by mine working women and children risked becoming homeless because of the 1842 Act. $^{21}$ Despite Stewart's pessimistic prediction, injured miners were not thrown out of their homes wholesale. Mine-owner paternalism remained strong in many mining districts after 1842 and company housing continued to be retained for vulnerable members of colliery communities, such as widows. ${ }^{22}$ Nevertheless, the dire forecasts made by opponents of industrial reform in the early $1840 \mathrm{~s}$ were probably not very comforting for incapacitated miners and their families and may have led to greater uncertainty about their future prospects. ${ }^{23}$

Women in mining communities made significant contributions to their families' economic well-being both before and after the passage of the 1842 Mines Act. The law may have stopped them working underground, but it did not stop them supplementing family income in other ways. Disabled mineworker Edward Rymer's mother, for instance, went gleaning for corn at harvest time to support her family during periods of pecuniary pressure, perhaps 'augmenting' her household's resources by as much as 10 per cent in the process. ${ }^{24}$ Many miners' wives also took in lodgers to help make ends meet. ${ }^{25}$ In times of difficulty some women may have taken even more desperate measures, resorting to theft to support sick or injured relatives. When Esther Morgan was charged with stealing forty pounds of coal from Ynyscynon Colliery tip in May 1864, for example, she claimed in mitigation 
that her father was a former miner and a 'cripple', and her mother was 'afflicted with cancer'. ${ }^{26}$

The economic input of women and children to disabled miners' households thus remained important after 1842, even if a greater premium was placed on the earnings of sons. As accounts of those killed in mining accidents demonstrate, the economic support provided by children continued as they matured into adulthood and was often vital for families containing disabled people. When twenty-three-year-old Alex Richards died in the Gethin Colliery explosion of 1865 , he left behind an old blind father and a sister who were 'supported solely by the deceased' ${ }^{27}$ Similarly, when a reporter for the Cambrian visited families of victims of the Abercarn disaster in 1878, he met a mother who had lost her twenty-one-year-old breadwinner son and whose husband was 'suffering from asthma and unable to work'. ${ }^{28}$ The loss of young people in colliery disasters was especially poignant in cases such as these where the support of sick, disabled or elderly family members was also at stake.

Despite the moral and legal pressure on relatives to support their own, people in coalfield communities could not always count on help from their families. The high mobility of coalminers, especially in north-east England where for much of our period pitmen were employed on a short-term basis via the annual bond, created a situation where wives and children might be deserted as men sought work in new collieries. In 1840 the Poor Law authorities in Easington (County Durham) complained that much of their time was spent pursuing 'fugitive husbands' ${ }^{29}$ Furthermore, in his 1842 report on the Scottish mining settlement of Tranent, S. Scott Alison claimed it was 'quite common for collier lads' in the area to abandon their 'helpless parents' without warning. He cited as an example a case he knew of 'an old, infirm, dying collier' whose 'son deserted him' one night. In the absence of filial support, the man was served an eviction notice. ${ }^{30}$ Newspaper reports also documented cases of neglect. William, David and John Howells, adult colliers, received a court summons in December 1886 for failing to contribute towards the maintenance of their seventy-year-old father, 'a cripple', who as a consequence had become chargeable to the Merthyr Tydfil Poor Law Union. ${ }^{31}$

\section{Public welfare}

As these examples show, the support of families was considered an important bulwark against a person becoming a 'burden' on public welfare. The extent to which coalminers and their families drew on the support of the state - in the form of the Poor Law - is a matter of some debate. Both at the time and since, coalfield communities have often been characterised as self-sufficient entities. 
Sick or injured miners, according to this characterisation, got by on their own or with the assistance of their families, friends or their employers and rarely had to resort to publicly funded welfare. In the early 1840s, John Wetherell Hays, Clerk of the Durham Poor Law Union, reported that there were few applications for poor relief or medical support from miners in his district since 'they have their medical aid in case of accidents at the expense of the colliery'. ${ }^{32}$ Charles Forrest, surgeon at Hirwain Iron Works, in south Wales, however, offered another explanation for the seemingly low pauper rates reported for miners in British coalfield communities. Under the Poor Law, both before and after its reform in 1834, entitlement to publicly funded welfare was usually dependent on a person's legal place of settlement, which was often their place of birth. As Forrest noted, this situation could pose serious problems for migrant mineworkers in the coalfields, particularly during times of incapacity. 'The bulk of the population not having legal settlements here', he observed, 'are of course removed to their own parishes whenever they become incapable by loss of limb or otherwise from following their work. The amount, therefore, of disabled men actually living here is very trifling indeed. ${ }^{33}$ Forrest's testimony suggests a reality greatly at odds with images of mining communities in which everyone - including paternalist employers, miners and local welfare officials all did their bit (even if reluctantly) to support disabled mineworkers. Instead of receiving help and kindness in the places they fell ill or were hurt, some sick and injured miners were simply turned away and told to look elsewhere for assistance. Clearly, not all coalfield communities were as willing to provide for the welfare needs of disabled people as some popular representations would have us believe.

Despite occasional reports of disabled miners being callously 'removed' from mining areas, however, coalfield settlements did develop ways and cultures of accommodating disability that meant most permanently injured mineworkers were probably able to stay where they were at the time of injury if they wanted to. As the coal industry expanded during the eighteenth and early nineteenth centuries an ethos of employer paternalism evolved with it - albeit one that did not provide an absolute guarantee of assistance after accidents. This was especially true for north-east England. During the early decades of the nineteenth century coal owners in the region mooted a scheme to help support the 'lame' or 'superannuated' among their workforce, funded by deductions from wages and a levy on the sale of coal. Although the scheme failed thanks to worker mistrust of their employers' motives, by the $1820 \mathrm{~s}$ a form of sick pay known as 'smart money' paid by employers to men certified incapable of work after accidents was becoming commonplace. ${ }^{34}$ The term echoed that used to describe payments to disabled naval personnel from the 
Chatham Chest, a mutual scheme established in 1588 jointly funded by the state and from deductions from seamen's wages. Describing naval 'smart money', Daniel Defoe wrote that it was 'honourable' that a 'Poor Man who Loses his Limbs (which are his Estate)' in the service of his country, and being thereby deprived of the ability to work, should not be 'suffered to Beg or Starve'. ${ }^{35}$ Adopting the term 'smart money' reflected the importance of mining as an industry crucial to national prosperity, while also reflecting employers' moral obligation to reward workers for their loyalty and sacrifice. With all its military associations, moreover, use of the term further shored up the image of miners as 'soldiers of industry' that was also becoming popular as Britain industrialised. While miners' 'smart money' originated in north-east England and was usually funded entirely by employers, by the mid-nineteenth century coal companies in other parts of Britain were also making similar kinds of payments to 'invalids' in their employ. ${ }^{36}$

While undoubtedly significant, voluntary support from employers, family and community was not always sufficient. Sometimes miners and their families had to draw on public welfare and this remained an important and frequently used safety net for them throughout the nineteenth century, despite the risk of removal under the Poor Law. ${ }^{37}$ John Leifchild challenged the characterisation of mining communities as proudly self-sufficient and averse to poor relief when he alleged, in the 1840s, that pitmen in north-east England had opposed their employers' earlier proposed welfare scheme there partly out of fear that it might 'deprive them of a claim to the poor rates'. ${ }^{38}$ Poor relief certainly sustained many miners. Parochial records for Wales and England reveal numerous examples of mineworkers who claimed long-term relief in the wake of serious injuries, such as Richard Thomas of Tonyrefail, Glamorgan. Starting in January 1830, Thomas received poor relief for at least a year (and possibly longer) following an 'accident in a colliery' and his inability to work. ${ }^{39}$ In the coalfield settlement of Houghton-le-Spring in County Durham, figures for 1837-41 indicate that around half of those on relief were from mining backgrounds. ${ }^{40}$ Furthermore, although employers might provide some medical support after accidents, this rarely covered illness or injury that occurred outside the workplace. In times of ordinary sickness, then, miners and their families who lacked other resources may have been forced to turn to parochial relief. As a witness to the 1844 Parliamentary Select Committee on Medical Poor Relief put it, in cases of 'protracted sickness' miners and their families in the north-east frequently ' $\mathrm{f}[\mathrm{e}] \mathrm{ll}$ upon the parish surgeon' ${ }^{41}$

The history of public welfare in late eighteenth- and nineteenth-century England and Wales has commonly been cast in terms of hardening attitudes towards the poor, represented above all by the passage of the Poor Law 
Amendment Act of 1834 (or 'New' Poor Law) that replaced laws that had operated since the Elizabethan period. ${ }^{42}$ Under the Elizabethan 'old' Poor Law, welfare provision was highly localised and often varied quite considerably from parish to parish. With the Poor Law Amendment Act of 1834, policymakers attempted to centralise the welfare system and reduce costs by making it more restrictive. Reformers wanted to create a system that was so unappealing to the poor that only the truly destitute would apply for relief. To ensure this, the new law was based on the twin principles of 'less eligibility' and the workhouse test. This meant that relief given to 'paupers' was supposed to be at a level substantially less than the worst paid labourers could earn. Furthermore, relief, especially to those considered capable of work, was only to be provided within the confines of a dreary and strictly regimented workhouse where inmates were required to work for their support. Under the new Poor Law in England and Wales, disability was regarded as quantifiable to some extent and impaired paupers were subject to classification as either 'partial' or 'totally' disabled. 'Partial' disability, which included general infirmity, was not considered a barrier to any labour whatsoever and within workhouses both the 'partially disabled' and the able-bodied were expected to undertake appropriate work 'suitable to their condition'. ${ }^{43}$

The new Poor Law was not uniformly implemented, despite the best efforts of reformers. For some Poor Law unions, such as Easington in the north east coalfield, building a workhouse was a 'grievous additional expense' and was resisted for several years. Overall far fewer workhouses were built than originally envisaged. ${ }^{44}$ Indeed, poor relief continued to be distributed for the most part outside institutional settings. ${ }^{45}$ As late as 1874 , fewer than one in five paupers (15 per cent) in England and Wales were receiving support in workhouses. ${ }^{46}$ Of those receiving aid outside institutional settings, moreover, a significant proportion were disabled people. Figures for the early 1870 s reveal that around half of those in receipt of 'outdoor' relief (not including 'Insane Paupers and Vagrants') were aged or disabled persons and their dependent children. ${ }^{47}$ Such relief could consist of cash or 'in kind' payments, or a combination of both. In kind payments included food, fuel, medicines, nursing attendance, clothing and rental subsidies. ${ }^{48}$

Nevertheless, the threat of institutionalisation shaped attitudes towards public welfare in significant ways. Like the 'respectable' poor more generally, miners viewed workhouses with disdain and tried to avoid them if possible. In his evidence to the 1842 Children's Employment Commission, the Reverend Mr Williams, a curate from Merthyr Tydfil, declared that there was a strong 'dislike' of the new Poor Law among the mine and metal workers in the town and that were a workhouse to be built 'prejudice is so strong that the people 
... would pull it down'. ${ }^{49}$ Similarly, in his evidence to the Select Committee on Mines in the mid-1860s, former miner John Normansell stated that 'we [miners] do not like the very name, to say nothing of the sight, of the union workhouse'. Though, as we saw in the previous chapter, some miners were able to benefit from medical care provided in workhouses, this antipathy towards the workhouse and the stigma associated with poor relief prompted many miners to join friendly societies or make other provisions for themselves. ${ }^{50}$

Significant regional differences in welfare provision persisted throughout the nineteenth century, both before and after 1834. The most glaring concerns Scotland, which had its own Poor Law system, different from that in operation in England and Wales. Prior to 1845, when the Scottish welfare system also underwent reform, the poor in Scotland had no absolute legal right to public relief, but were dependent on the goodwill of local men of standing. In 1842, S. Scott Alison noted that it was unlikely that a miner in Tranent would get poor relief 'unless he is very ill indeed'. So 'urgent' was their 'distress' that many 'even in this frail state go out to the colliery, and do a little work', and Alison reported that he had known 'several people so situated suffer serious injury in consequence'. Indigent miners and other poor persons, moreover, were only allowed to apply for relief twice a year. This meant they could not apply when need arose, but had to wait for a designated application period to come round. ${ }^{51}$ Although some parishes did allow 'occasional supplies' for those who fell into 'accidental distress', the welfare system observed by Alison in Tranent was slow to respond to the needs of the poor and ' $[\mathrm{g}]$ reat privation' was 'sometimes experienced by deserving people' because of the time they had to wait for their applications to be 'attended to'. 52

In 1845, this situation changed and the poor in Scotland became entitled to welfare providing they were considered incapable of work..$^{53}$ Whereas the Poor Law operating in England and Wales provided relief for both able-bodied and disabled paupers, in Scotland disability - 'whole' or 'partial' - was made the chief criterion for support. Defining a claimant as 'disabled' might be a contested process. Poor Law records in Scotland reveal a number of cases where the presence of impairment was not deemed sufficient to grant relief. Hugh McKay, a miner, made an application for assistance from the parish of Carluke in Lanarkshire on behalf of his eldest son who was subject to epileptic fits, only to be refused on the grounds that his son was considered 'ablebodied'. ${ }^{54}$ In Glasgow several years later it was ruled that a young man aged 26 was not eligible for parochial relief since he was 'physically able to earn eleven shillings per week', although he was 'to some extent mentally incapacitated'. ${ }^{55}$ Definitions of both disability and destitution were elastic and could depend on local economic circumstances that might affect an injured or impaired 
person's ability to earn a living. 'Want of light remunerative employment is one great cause of pauperism,' noted a report on the Poor Law administration in Scotland written in the early 1870s, and it was 'not uncommon to give relief to persons who are not disabled for some kind of work, if it were available'. ${ }^{56}$

When Parliament reformed the Scottish public welfare system in 1845, it did not insist, as it had done for England and Wales, that workhouses be built or require the institutionalisation of paupers. The new law left much of the old system intact. Parishes continued to be the administrative unit through which relief was distributed. Paupers were entitled to medical relief and it was the duty of local Poor Law officials to make sure they got this. Parishes could, if they wanted to, provide this within a poorhouse, but they were not compelled to do so. Moreover, in sharp contrast to the workhouses envisaged by policymakers for England and Wales, Scottish poorhouses were not intended - in theory at least - to serve as deterrents to pauperism and conditions within them were not set according to the principle of 'less eligibility'. Instead, poorhouses were to serve as refuges or shelters for those 'poor persons who from weakness, fatuity of mind, or by reason of intemperance, dissipation or improvidence, are unable or unfit to take charge of their own affairs'. The official emphasis was on providing them with a 'place of security, and seclusion from the world' where their 'necessity ... to live by alms' could be tested, rather than punishment or deterrence. ${ }^{57}$

Nevertheless, in practice poor relief in Scotland was, according to Hutchison, 'administered in such a way as to make it an unattractive solution and to encourage claimants or their relatives to seek alternative remedies to poverty'. There may have been no formal workhouse test in Scotland, but, as the nineteenth century progressed, poorhouses also became more regimented, austere and disciplinary places and worked to discourage all but the totally destitute from seeking relief within their walls. ${ }^{58}$ By 1868 , Scotland had sixtysix poorhouses, which, on average, accommodated around 8,000 to 9,000 paupers annually. Demand for places in them, however, rarely outstripped supply. In 1868, for instance, Scottish poorhouses may have housed thousands of paupers, but, with capacity for approximately 12,000 inmates, they still had plenty of space for several thousand more. ${ }^{59}$

In some cases, such as that of Nicholas Winn, 'a drawer or coal-pit worker ... in delicate health', those offered relief by Poor Law officials in Scotland were sometimes given a choice as to whether they were institutionalised. The medical officer who attended Winn in the late 1850 s offered him a place in a poorhouse, where it was thought the mineworker could be better cared for than in his current lodgings. Winn, however, refused the offer and was instead provided for by the Parish of Old Monkland outside the poorhouse 
in private accommodation. ${ }^{60}$ Yet inspectors in other parishes might take a different approach. In Dalziel, North Lanarkshire, a collier, Thomas Campbell, 'partially disabled by asthma', was granted relief in the poorhouse but after refusing to go he found his support denied. Several other disabled colliers in that parish found themselves in similar circumstances after refusing to enter the poorhouse. ${ }^{61}$

Nevertheless, as in England and Wales, most paupers in Scotland were provided for outside the walls of publicly funded welfare institutions through a similar combination of monetary assistance and 'in kind' benefits, including 'meat and clothes' or assistance in attending hospital. ${ }^{62}$ The notes appended to applications for relief from parochial officers provide important insights into the causes of disablement in Scotland's coalfield communities and the experiences of those miners who received relief. To take one mid-nineteenthcentury example, the records of applications for relief in the parish of Carluke near Glasgow reveal a variety of physical and mental impairments that prevented mineworkers from undertaking their usual work. While many claimed relief after accidents, or as a result of the incapacitating lung diseases that were endemic in many Scottish coal mines, some mineworkers became 'disabled' thanks to other events. For instance, James Watson, a married man aged fortythree, who made an application for relief on 18 July 1856, was categorised as 'wholly' disabled due to his 'labouring under some melancholic delusion as to his future state and quite unfit to follow his employment'. His application for relief was referred to committee, where, upon receipt of medical evidence, he was admitted to the lunatic asylum in Glasgow. ${ }^{63}$ James Fyfe, a fourteen-yearold drawer at a coal pit, applied to relief on 12 May 1858 because he had been 'severely bit by a dog and is unable to work'. ${ }^{64}$

Being classed as 'wholly' disabled did not necessarily mean a person was considered permanently impaired. George Moffat was declared 'wholly disabled' due to an 'attack of Bronchitis', but was 'expected soon to be able again for his usual employment' ${ }^{65}$ Indeed, the records often made distinctions between those declared 'wholly' disabled and those who were 'wholly at present' incapacitated from working, indicating an understanding of disability as a fluid, rather than permanent, state. ${ }^{66}$ Showing concern about the future liabilities of the parish, many notes commented on claimants' likelihood of recovery. Thomas Kerr, whose application for relief was received in December 1859, was classed as 'wholly disabled' due to an inflammation of the internal ear, 'his recovery very doubtful'. Similarly, John McKendrick applied in the same month with a broken back, which the inspector feared was 'so serious that he will never recover' ${ }^{67}$ The administrative records of poor relief from Carluke furthermore reveal that the authorities were familiar with the diseases 
of mineworkers and this allowed them to make subtle distinctions between types of impairment and their likelihood for improvement. Thus, men temporarily impaired through attacks of bronchitis were distinguished from those such as Samuel Donaldson, a thirty-one-year-old miner, who was described as 'one of those cases of miners becoming useless in the breathing apparatus from this employment before they reach the prime of life'. Though classed as wholly disabled 'at present', the notes did not indicate much faith in his likelihood of recovery. ${ }^{68}$ Just like their counterparts in England, whose processing of disabled applicants has been analysed by Steven King, the parochial authorities in Scottish mining communities made distinctions and judgements that indicated a nuanced understanding of different impairments and their effects on individuals' lives. ${ }^{69}$

Overall, despite the endeavours of national policymakers and administrators to centralise poor relief, local Guardians of the Poor still exercised a lot of discretion during the nineteenth century. The overwhelming and persistent reliance on outdoor relief in many places indicates the autonomy of local officials in determining how to tackle poverty in their communities. Although large-scale disasters, economic downturns and strikes might place the Poor Law in mining areas under considerable strain and lead to greater scrutiny of claimants, under other circumstances the authorities might respond 'flexibly and imaginatively' to the financial problems faced by sick or injured mineworkers. ${ }^{70}$ While Poor Law officials expected mineworkers to plan for their own welfare needs via voluntary schemes such as workplace accident funds or joining benefit societies, they provided support for those who were unable to maintain their payments to friendly societies or whose benefits fell short of providing enough to live on. Under the old Poor Law, overseers made ad hoc payments to colliers and others to subsidise their subscriptions to self-help organisations, such as the one-off payment of 5s. to Thomas Llewellin in Miskin Hamlet near Llantrissant in south Wales in July 1817 'for his Benefit Club'. ${ }^{71}$

After 1834, guardians in English coalfields also seem to have used their autonomy to favour injured miners for outdoor relief, even though the preference of national policymakers at the time was for greater use of workhouses. ${ }^{72}$ In the aftermath of colliery accidents, guardians were also known to disregard the friendly society benefits paid to miners when deciding what allowances to give them, despite requests from London that they should take these into account. In ignoring these national recommendations, guardians wanted to reward miners who had been prudent enough to make provisions for sickness or injury and reinforce the message that those most worthy of poor relief were those who had done everything in their power to stave off penury. ${ }^{73}$ 


\section{Voluntary welfare}

Important as the state was in times of hardship, voluntary and self-help schemes were arguably more important in providing relief for those who became sick or injured in the workplace. ${ }^{74}$ Voluntary welfare provision was generally either reactive or proactive in nature. Reactive measures were responses to welfare needs that had already arisen. As we have seen, employer paternalism was an important part of reactive welfare provision for injured miners; so too were informal community responses to accidents, including ad hoc 'gatherings' to help disabled mineworkers get established in other lines of work. ${ }^{75}$ Charitable appeals ranged from ingenious efforts on behalf of individuals, such as the raffle reportedly held in Merthyr Tydfil in April 1857 to 'enable some unfortunate youth to purchase a wooden leg', to the impressive disaster-relief funds assembled in the face of large-scale casualties that threatened to overwhelm normal sources of support. ${ }^{76}$ Although primarily established for the benefit of the bereaved, disaster funds, such as one set up after the Abercarn explosion in 1878 , also paid out money to injured survivors. Donations to these funds came from coal owners, mining communities and, thanks to the publicity given to such disasters in the press, from people living beyond Britain's coal producing regions. ${ }^{77}$ In May 1880, for example, The Times reported that more than a half of the $£ 59,000$ collected for 'sufferers' of the Abercarn disaster came from a fund based in London. ${ }^{78}$ Such reactive measures to mining accidents were heralded and encouraged as signs of Christian charity.

Alongside such community responses, nineteenth-century Britons were also expected to take proactive measures to mitigate the effects of future misfortune. Victorian reformers such as Samuel Smiles promoted self-help initiatives as a means of encouraging 'self-reliance and self-respect' among the working classes. ${ }^{79}$ Accordingly miners, like other workers, were increasingly expected to take responsibility for their own future welfare needs by contributing to benefit or friendly societies. If, on the one hand, hostility to the workhouse test may have made state welfare degrading in the eyes of proud coalminers, on the other those who relied on the Poor Law sometimes faced stigma for their alleged imprudence. Layton Lowndes, chairman of the Board of Guardians in the coalmining community of Madeley, Shropshire, giving evidence to the Friendly Societies Commission of 1873, remarked of colliers that their improvidence often meant that they made inadequate payments into benefit societies to cover sickness. Miners were, he noted 'getting very high wages on short hours', but squandered them in the public house rather than using them responsibly to safeguard their families' well-being. ${ }^{80}$ Although this stereotype of the thriftless miner has been comprehensively challenged, the 
impact of voluntary welfare on the experiences of sick or impaired mineworkers has received less attention. ${ }^{81}$

Arguably the most important vehicles for insuring against sickness and injury in the nineteenth century were friendly societies. Their core aims were to provide insurance against ill health in the form of sickness benefits to members too incapacitated for work, and payment for a respectable funeral. Emerging during the eighteenth century as a response to industrialisation, there were an estimated 7,200 friendly societies in 1801 with a membership of 648,000 - about 6 per cent of the population. ${ }^{82}$ As the century progressed, the significance of friendly societies grew along with their membership. By 1913, an estimated one in six of the British population belonged to a friendly society. ${ }^{83}$ Throughout the nineteenth century, mining areas had some of the highest friendly society membership rates in Britain. ${ }^{84}$ That they did, reflects a realisation by miners and their families that ill health and injury were inevitable consequences of mining. ${ }^{85}$ It was also an acknowledgement that bodily incapacity could cause disruption to their household economies, as the labour of key contributors was diminished. When deciding who to insure against sickness or injury, then, families tended to prioritise male breadwinners over other household members. ${ }^{86}$

For some mineworkers, joining a friendly society was an important rite of passage marking their first steps towards responsible manhood. Recalling his youth at the end of the nineteenth century, Edmund Stonelake wrote that he had been encouraged by his mother to join a friendly society as soon as he began to earn a 'man's wage', in order to maintain his 'independence' in the face of sickness or accident. Stonelake took the ethos of self-help to heart, noting that his favourite reading at the time was Ralph Waldo Emerson's essay, Self-Reliance (1841). ${ }^{87}$ Friendly societies did not simply provide welfare relief, but also cultivated an ideal of working-class manliness based on co-operation, independence and responsibility. ${ }^{88}$

Friendly societies took many shapes and forms. They could be broad organisations whose membership was drawn from many occupations, or confined to a single occupation. Additionally, they could be compulsory, entirely voluntary, national or local in nature. In the mining areas of west Scotland, some friendly societies reflected sectarian loyalties, with separate Catholic and Orange Order benefit organisations emerging by the 1860 s and 1870 s. ${ }^{89}$ Miners joined every type of society, though they often faced hostility from general organisations that recruited from a broad spectrum of workers. Aware of the greater bodily risks that mining involved, and fearful that mineworkers would place an excessive burden on their funds, some societies banned colliers from joining altogether. The Star Friendly Society, formed at the Three Cranes 
in Pontypool in 1831, for example, forbade 'any Collier or other underground workman, or persons working in Lead or Copper works' from joining and warned that if any member shall go to work in any underground work, and receive any hurt there, he shall receive no benefit from this society for such hurt'. ${ }^{90}$ Given this hostility, mineworkers often joined societies established specifically to cater to their needs, or formed societies of their own. Examples of such occupational societies include the United Colliers and Miners' Society based in Pontypool, established in 1831, the Beamish Colliery Friendly Society in County Durham (1835) and the Carfin Colliery Friendly Society of Lanarkshire. ${ }^{91}$ Some, like the Rickleton and Harraton Outside Collieries' Relief Fund, established in 1833, were heavily influenced by mine owners who appointed officers and managed the funds and differed little from compulsory pit clubs; others were run by miners themselves. ${ }^{92}$

Local schemes had advantages and disadvantages. Of the advantages, local societies were generally quite small so members had a good chance of knowing each other personally. For disabled miners, these personal connections may have made benefit applications easier and increased the likelihood of a successful claim as familiarity and trust were important factors in welfare provision more generally in late eighteenth- and early nineteenth-century Britain. ${ }^{93}$ For the societies, this intimate knowledge of their membership meant they had an appreciation of the personal circumstances of claimants, so were in a good position to guard against fraudulent applications. ${ }^{94}$ However, local societies also presented a number of problems. Their small membership base meant that their benefit funds were not very large and there was always the risk that they may become insolvent, especially when mining disasters struck and multiple claims were submitted at the same time. ${ }^{95}$ Furthermore, as social commentator Frederick Morton Eden noted in 1801, the localism of small societies could restrict the geographical mobility of insured workers, as many imposed residential requirements of one sort or another on members. ${ }^{96}$ To be sure, some local societies did allow members to move away and still retain their right to benefits, but these societies were often ill prepared to examine, monitor or pay claimants in far off places. They were simply too small and lacked the personnel and structure to effectively administer benefits over long distances. Consequently, members who lived beyond a local society's home territory often faced additional hurdles if they wanted to claim benefits, such as having to provide legal documentation to prove their sickness or give notice of their movements. ${ }^{97}$ For members living a long way from their societies, keeping up regular membership payments to maintain their cover could also prove challenging. Given that British miners were a geographically mobile people, local societies were not ideal vehicles for providing them with 
the kind of sickness and incapacity cover their itinerant and dangerous lives necessitated.

During the course of the nineteenth century, friendly societies became much better at meeting the needs of the highly mobile industrial workforce, thanks largely to the growth of the so-called affiliated orders. ${ }^{98}$ These were friendly societies, such as the Ancient Order of Foresters or the Order of Oddfellows, that were national in scope and had large inter-occupational memberships. Due to their wide membership base and national reach, these organisations had larger funds than local societies and were generally based on firmer actuarial foundations. Proudly independent organisations, they were also more reliable and allowed members to move around the country in search of work and still maintain their accident and sickness cover. They were also more likely to allow colliers to join their ranks than other societies, and for many miners the affiliated orders offered a valuable alternative, or supplementary source of support in times of sickness, to that provided by compulsory pit clubs. ${ }^{99}$ These national societies became increasingly important to the mixed economy of welfare in coalfield settlements as the nineteenth century progressed. By 1863, their ubiquity in the colliery communities of north-east England was so great in fact that Dr Robert Wilson felt confident enough to state that '[i]n all [pitmen's cottages] but the Skip Jack, you find the emblem of either the Foresters', Oddfellows', or Free Gardeners' Benefit Society.' ${ }^{100}$

Although the affiliated orders may have been more accommodating to mineworkers, however, concerns about coalminers' susceptibility to accident and illness persisted and led to calls for differential treatment. Statistics on illness cover provided by friendly societies returned to Parliament in 1853 showed that at age twenty the sickness rates amongst colliers were 36.44 per 100 , compared to an average for England and Wales of 26.62, which rose to 38.96 by the age of forty-five and 50.52 by the age of sixty. While many friendly societies sought to keep their costs down by excluding new members from joining above the age of forty-five, the higher levels of sickness among younger coalminers relative to other occupations led to increasing calls for miners to pay more for friendly society benefits. ${ }^{101}$ A witness to a parliamentary select committee in 1849 suggested that 'workmen in coal mines and iron mines' ought to pay contributions 'probably twice as much as the agricultural population should pay'. ${ }^{102}$ After debating whether 'under ground workmen should be admitted on the same footing as other work men', the Bute lodge of Oddfellows in Llantrissant agreed in 1873 to admit miners on condition that their benefits would be a shilling per week less than those paid to 'any other workman'. 103

By this time, it was becoming common for some societies to charge 'miners 
and colliers' a 'special rate as to sickness'. ${ }^{104}$ As F. G. P. Neison wrote in an article, 'The Influence of Occupation on Health' published in The Foresters' Miscellany in 1874, the particular liability to injury or sickness of different occupations made a monolithic approach to sickness benefits impractical, since injuries that would 'suffice to disable sawyers, colliers, or miners, would have but little effect on those following quiet and sedentary occupations'. Therefore, he argued, societies should adapt their rules to the occupational composition of their members. ${ }^{105}$ Although members of the Foresters opposed plans to charge higher membership rates for miners in the late nineteenth century, arguing that the average numbers of sick days claimed by coalminers was in fact not significantly higher than for other workers, symbolically at least the greater exposure to risk faced by colliery workers bolstered calls for differential treatment. $^{106}$

Regardless of their respective strengths and weaknesses, all friendly societies shared certain similar characteristics. As Simon Cordery notes, in general, most societies 'had age, health, occupational, and moral prerequisites to membership'. ${ }^{107}$ Many required potential members to be free of ill health or impairment at the time of joining. Good health and good moral character were inextricably linked in the membership requirements of many societies. ${ }^{108}$ For instance, the rules of the Kilmarnock Coal Cutters Friendly Society, established in 1834, stated that 'all persons admitted ... must be of a good moral character, free of bruise or any bodily infirmity and capable to gain a livelihood for himself and family'. It also encouraged members to report others who might be concealing a 'bodily infirmity' when they joined. ${ }^{109}$

Many societies similarly used moral criteria to define injuries or impairments worthy of financial assistance. The Sons of the Globe in Monmouthshire declared that if any of their members 'shall be disabled by gambling on the Sabbath day he shall receive no relief from the fund for such his misfortune', and only provided relief for those 'disabled by fighting' if it could be proved that they were not the 'aggressor'. Those who might 'wilfully maim or hurt' themselves or 'feign sickness, lameness, or other acts of dissimulation' to gain relief would be expelled. ${ }^{110}$ The long list of exclusions set out by the St George's Friendly Society in 1820, including ill health caused by 'venereal disease, old ulcers, sores, jumping, wrestling, fighting, gaming, hunting, or any other improper conduct, or from being concerned in any riot or mob', was typical of many in using the causes of illness or injury, rather than its consequences, in determining access to benefits, using moral criteria to draw distinctions between 'good' and 'bad' sick and disabled claimants that reinforced centuriesold distinctions between 'deserving' and 'undeserving' applicants for relief. ${ }^{111}$ Although some men balked at the puritanism of some societies - such as those 
who worked at Graig Colliery in Merthyr Tydfil who, as a witness to the 1842 Children's Employment Commission noted, 'cry out against the bastardy clause' - many still availed themselves of their services. ${ }^{112}$

To ensure moral probity, those applying for benefits were often required to mobilise the support of respected persons to verify their claims. Indeed, these same figures were also regularly called upon to examine and certify the incapacities of applicants. In the first half of the nineteenth century, examination of claimants was 'social' as well as 'medical' with prominent laypersons providing support for applications alongside doctors and surgeons. ${ }^{113}$ As late as 1873, the Tranent Miners New Friendly Society ordered claims to be verified either by a surgeon or a 'minister of some religious denomination', suggesting that medical authority in defining sickness was not yet absolute. ${ }^{114}$ The involvement of lay persons alongside medical experts is evident in the extensive correspondence that survives for the Glais Friendly Society, located at Llansamlet near Swansea. Although a 'surgeon' certified some claims, other applicants had their applications additionally verified by clergymen, churchwardens or representatives from their place of work. Therefore when John Morgan of Llansamlet applied for assistance when he became unable to work due to a 'sore leg' in 1844, his application was certified by a surgeon, a churchwarden, the parish curate and David Lloyd, the agent for Cymllynfell Colliery where he presumably worked. ${ }^{115}$ Henry Rees's claim in the summer of 1857 was similarly supported by a surgeon, an independent minster and Thomas Walters, a colliery overman. ${ }^{116}$ A good relationship with colliery managers, then, was clearly important for some mining claimants, though it was rarely an absolute requirement for a successful claim. The significance of doctors in the affairs of nineteenth-century friendly societies also varied. During the first half of the century, societies tended to employ doctors primarily in a 'policing role', screening applicants for relief where needed. In the late 1830s, for example, Hebburn Colliery Relief Society allowed its officers to consult surgeons for their opinion in cases of suspected fraud. ${ }^{117}$ With time, however, doctors generally became more central to the business of friendly societies and they were increasingly called upon to provide members with medical care as well as validate claims. By the end of the century, doctors were used by friendly societies almost as much for their therapeutic skills as for their supposed ability to assess the cause and extent of sickness objectively. ${ }^{118}$

To guard against fraud and ensure that they maintained their good moral character, society officials also visited the sick and incapacitated regularly. ${ }^{119}$ For claimants, including disabled miners whose impairments were acquired after the start of their membership, such visits may have been considered intrusive and viewed with trepidation. Patients were expected to adopt a 'sick 
role' in which they agreed to passively submit to medical advice and to remain confined to their homes. ${ }^{120}$ While claiming sickness benefits, members of Wishaw Iron Works Miners' Annual Friendly Society were expected to avoid 'public places of amusement', refrain from drinking or gambling and 'shall not leave home without obtaining and handing to the President a Doctor's certificate that his going from home is for the good of his health'. ${ }^{121}$ At the same time, however, the visitations made by society stewards could be a source of comfort, especially in small local societies where stewards were more likely to be personally acquainted with benefit recipients. ${ }^{122}$

Payments from friendly societies varied and for smaller societies might depend on the overall health of the fund. Some injuries merited higher payments. In south Wales, the rules of a friendly society at Risca made in 1817 , for example, allowed weekly payments of between three shillings and ten shillings, depending on the financial state of the society, but specified a minimum payment of one guinea ( $£ 1$ s) if a member lost a limb and allowed additional relief for members with broken bones. This was in recognition of the higher medical costs involved in treatment. ${ }^{123}$ Isaac Williams a collier member of the Sons of the Globe Society of Pontypool, received a one-off payment of $£ 117 \mathrm{~s}$ $3 \mathrm{~d}$ 'all[owe] $\mathrm{d}$ for broken bones', together with weekly sick pay of four shillings in $1821 .{ }^{124}$ However, most societies were not geared up to meeting the longterm welfare needs of disabled claimants. Some societies ceased their support completely after a period of time, placing members under pecuniary pressure. In Merthyr Tydfil in 1849 it was reported that some of the 184 men relieved by the Poor Law Union were victims of accidents in the town's collieries or iron works who had become 'burdensome to the parish' because they had 'exhausted their "sick fund" or "benefit society" allowance. ${ }^{125}$ Most societies reduced payments after several months. Carfin Colliery fund, for example, paid $6 \mathrm{~s}$ a week to those 'disabled from working', which was reduced to $5 \mathrm{~s}$ after four months and $4 \mathrm{~s}$ after eight months. If the claimant had not recovered after a year 'he shall be placed on the superannuation list which is declared to be two shillings weekly.'.126

There is anecdotal evidence that in some areas workers may have drawn on several benefit societies to help make ends meet. David James, chairman of the Merthyr Board of Guardians, told the Morning Chronicle's reporter in 1849 of a man who earned $14 \mathrm{~s}$ a week at work, but when certified sick earned $18 \mathrm{~s}$ a week $-7 \mathrm{~s}$ from each of two friendly societies he had joined, and $4 \mathrm{~s}$ from his work's sick fund. ${ }^{127}$ The idea that workers' sickness benefits might exceed their wages caused considerable concern for 'respectable' Victorians. ${ }^{128}$ Indeed, some societies were so worried about this possibility that they guarded against it by expressly prohibiting members from belonging to more than one society 
at a time. ${ }^{129}$ For most people, however, reliance on benefits from a society undoubtedly represented a drop in income. In the late 1830s and early 1840s, Tranent miners claiming sickness payments from a 'benefit society' were reported to receive five shillings a week, at most. Considering that colliers in the area at the time were reputedly able to earn twenty shillings a week quite comfortably, the benefit available to disabled miners can hardly be regarded as generous. At around a quarter of what a miner might expect to earn at work, receipt of such benefits would have meant a significant fall in income for mining households. They were, in short, a poor compensation for a full loss of a miner's earnings. ${ }^{130}$

Unlike the Poor Law's distinction between 'whole' and 'partial' disability, friendly societies generally adopted a simple concept of incapacity in which a person was either able to work or not. The rules of most societies prohibited payments to sick and injured members who worked. ${ }^{131}$ There were occasional exceptions. In 1857, the Oddfellows Bute Lodge in Llantrissant agreed to pay $£ 10$ to a quarryman, Richard Williams, 'to enable him to commence some business in consequence of the loss of his hand from an accident', in lieu of weekly payments. ${ }^{132}$ However, for the most part, miners and other workers with long-term health problems had to choose between receiving a meagre benefit and working as best they could. Without doubt, friendly societies offered a significant safety net for miners and other nineteenth-century workers that fostered pride in self-reliance, and was free from the stigma of the Poor Law or (in many cases) the controls of employer paternalism. But for most miners in receipt of sickness benefits, societies worked in such a way as to deprive them of a means of supplementing their incomes through light work, which might relieve some of the financial pressure injury and illness placed on them and their families.

\section{Permanent relief funds and the politics of welfare}

As the nineteenth century wore on, the problem of how to effectively support the long-term welfare needs of disabled coalminers and their families attracted other solutions. Trade union accident funds, which are examined in more detail in Chapter 5, operated in similar ways to friendly societies. ${ }^{133}$ In the second half of the century, life insurance companies also sensed a commercial opportunity in providing cover for workers in collieries and other dangerous occupations. ${ }^{134}$ For example, The Miner and Workmen's Advocate, the self-declared 'Publication devoted to the interests of the Working Classes of the United Kingdom', recommended that its readers join the Friend in Need Life Assurance company, citing the weakness of friendly societies in 
providing adequate cover in cases of chronic sickness or old age. Faced with the daily threat of being 'lamed, crushed, blinded, burnt and injured in every conceivable way', readers were told to 'select a proper institution and insure at once'. ${ }^{135}$

However, the most significant step towards tackling the long-term needs of disabled mineworkers was taken in the aftermath of the Hartley Colliery disaster, which claimed 204 lives in January 1862. The accident led not only to an outpouring of public sympathy, but also triggered debates about how the victims of all mining accidents should be supported. In spite of raising some $£ 85,000$ in a disaster-relief fund to help the bereaved, the response to the catastrophe 'highlighted to miners of the north the injustice of a system that overprovided for families of [victims of] disasters', while not providing long-term support for those whose loved ones were killed 'singly' in quotidian accidents that never 'reached the public ear'. It led to calls for more durable systems of support so that miners permanently disabled did not have to rely on ad hoc fundraising, nor pit clubs, which 'seldom make substantial provision for more than a few months of disablement'. ${ }^{136}$ These concerns became the catalyst for the formation of the Northumberland and Durham Miners' Permanent Relief Fund.

The fund had two main objectives: providing relief for widows and orphans of men killed in mining accidents and providing support for the long-term disabled. It was established on 7 June 1862 and within two weeks had 2,000 members from thirty collieries. By October that year its membership had risen to 7,560 from sixty-one collieries and by the end of its first year it had almost 8,000 subscribing members. ${ }^{137}$ In 1863 , surplus money from the Hartley Relief Fund was amalgamated into the Northumberland and Durham Miners' Permanent Relief Fund. By the time of its second annual report in May 1864, the fund was reported to be in good health, despite the expenditure on permanent disablement being 'far greater than had been expected'. There were nine adults and two youths receiving disablement benefits costing $£ 205$ 0 s $8 \mathrm{~d}$ a year (about a quarter of its expenditure). ${ }^{138}$ By 1868 , membership had grown to 11,000 and despite initial scepticism about the likely success of the scheme, many colliery owners were now encouraging their workers to join. The proprietor of Walbottle Colliery, for example, offered men an additional three shillings a week smart money for members as an inducement for men to join the scheme. ${ }^{139}$ By the 1870 s, colliery owners were actively subscribing to the fund, contributing $£ 20$ for every $£ 100$ they paid to their workers. ${ }^{140}$

The permanent relief fund aimed to support the victims of serious accidents, such as where limb amputation had taken place or where men had received spinal damage 'whereby [they were] not able to work any longer'. 
In an attempt to distinguish between longer-term conditions and temporary impairments, payments started after twenty-six weeks' absence from work. As Alexander Blyth, secretary of the society, reported in 1872, disabled members received eight shillings a week, paid for by membership fees of three-and-a-half pence a week. The fund differed from conventional friendly societies in that it aimed to assist those permanently disabled in mine work (as a result of accidents on the surface as well as underground), and potentially made payments in perpetuity. However, in response to the objections of some members about having to wait half a year before they received any benefits, a 'minor accident' fund was established in 1869. This promised five shillings a week to injured members during the first twenty-six weeks of incapacity. After that, if they were still unable to work, they were transferred to the permanent relief fund. To enable this transfer between schemes, only men who were already members of the permanent fund were allowed to sign up for the 'minor accident' fund. In addition, there was also a sickness fund, which varied its payments according to the age of members, although this was not well used. The Northumberland and Durham Permanent Relief Fund therefore offered a variety of benefits, providing similar services to friendly societies as well as more innovative longterm relief to the permanently disabled. ${ }^{141}$

Two-thirds of members, estimated Blyth, were also members of friendly societies such as the Foresters or Oddfellows, showing that the permanent relief fund was expected to supplement rather than replace other forms of support. In providing higher payments to long-term disabled members, compared to those disbursed to victims of 'minor accidents', however, it marked a distinct change from normal friendly society policy. ${ }^{142}$ Whereas friendly societies customarily reduced their payments over time, the permanent relief fund recognised the long-term needs of its disabled members. Its principles were adopted elsewhere. Proposals for a Scottish Permanent Relief Fund in 1878 similarly recommended payments of eight shillings a week for miners disabled and 'unable to gain a livelihood in any other employment' and proposed payments at the same level for both widows and 'dependent relations of permanently disabled members' - a decision that equated permanent incapability to earn a living with death. ${ }^{143}$ By 1880 , permanent relief funds were found across English coalfields and had enrolled a fifth of the country's miners. ${ }^{144}$

The first disabled claimant of the Northumberland and Durham Miners' Permanent Relief Fund was Henry Baker of Backworth Colliery, who received help from 8 January 1863 to his death in March $1875 .^{145}$ By 1880, the income from the 70,663 members of the Northumberland and Durham fund was around $£ 37,380$, providing support for some 232 permanently disabled members and 1,110 'aged miners'. ${ }^{146}$ Nevertheless, the permanent 
relief fund faced a number of problems and criticisms. Like other welfare schemes there were fears that it was open to fraud, and from an early stage the Northumberland and Durham fund engaged the services of medical men to enquire into 'all cases of permanent disablement' and to regularly examine 'disabled members'. ${ }^{147}$ Administrators of the disablement fund also faced 'many and great difficulties in determining the difference between diseases arising from natural causes and diseases caused by accidents. ${ }^{148}$ The cost of supporting long-term 'disablement' also threatened the financial health of the fund. In 1864 the Northumberland and Durham Permanent Relief Fund passed a motion to 'grant a disabled member a sum of money wherewith to commence business' in place of paying future claims, in the hope that those capable of some work would take the opportunity to be self-sufficient. ${ }^{149}$ Strikes, such as the one in north-east England in 1879, reduced membership payments, putting pressure on resources. ${ }^{150}$ The large number of disabled and aged miners taking advantage of the scheme by the end of the 1870 s led to calls for some funds to raise membership subscriptions. ${ }^{151}$

The partnership with employers - who assisted with the management and administration of the funds - and the local, rather than national, organisation of the movement, also raised concerns. ${ }^{152}$ At its inception, the Northumberland and Durham scheme was criticised in the pages of The British Miner and General Newsman and Miner and Workman's Advocate as being merely a 'local fund', built on 'sandy foundations', where the involvement of mine owners made recipients vulnerable to losing their benefits for 'presumed insubordination'. ${ }^{153}$ This animosity stemmed from initial talks between the Permanent Relief Fund Society and the National Association for the Relief of British Miners led by trade unionist John Towers, at which the latter had insisted that the permanent relief fund come under its auspices. ${ }^{154}$ Towers used his British Miner newspaper to advocate a national, trade-union-led solution to the problem of death and disablement. Alongside paying benefits to dependents of those killed in accidents, providing 'such suitable provision as the case may require' in cases of disablement and a superannuation allowance to the aged or incapacitated, the National Association (which later became the British Miners' Benefit Association) also promised to fight for improved safety to prevent accidents from occurring in the first place, arguing that a 'radical cure' was better than 'palliative' care. ${ }^{155}$ As Blyth noted in 1872, this was 'more a political society than a benefit society' and despite offering the appeal of independence, it was seen by supporters of the permanent relief fund as impractical since it was 'not likely to get the support of the owners of the collieries' needed to secure long-term financial success. Eventually it foundered. ${ }^{156}$ Nevertheless, as permanent relief funds became established in other coalfields and expanded 
their membership, the need to form a national umbrella organisation to oversee the administration of the scheme was eventually accepted. ${ }^{157}$

\section{Conclusion: disability, eligibility and welfare}

The experience of welfare in the coalfields was marked by variability. Sick, injured and impaired miners could have very different experiences depending on when, where and who they asked for help. The 'mixed economy' of welfare that sustained disabled mineworkers and their families in times of need was multi-faceted. Its three main components, domestic, voluntary and public welfare, were closely inter-related and in times of distress a miner might draw on several sources of support simultaneously. Although reliance on public welfare called into question a person's respectability, it did provide an important safety net for many disabled miners. ${ }^{158}$ Stories of workers profiting from their incapacity by combining benefits from multiple sick pay schemes to earn more than they did at work were probably apocryphal. Most injured miners struggled to get by on benefits that usually fell far short of their normal wages. That such stories circulated, however, indicates the deep suspicion of welfare claimants in nineteenth-century Britain, as well as the expectation that miners, with their relatively high pay, would make their own provisions for incapacity. This expectation was embodied in the cultural ideal of 'heroic self-dependence', of the man who strove to retain his independence in the face of misfortune. It was also reflected in idealised portrayals of miners who refused to become a 'burden' on the poor rates and chose instead to work through their impairment. Giving a lecture on 'eminent miners' to Bristol Mining School in March 1857, colliery owner Handel Cossham related the story of a Cornish tin miner, 'the Blind Miner of Bottalack', who worked in a mine in spite of his visual impairment so that he could support his 'large family' and avoid reliance on poor relief. 'This noble miner has left an example of true independence,' concluded Cossham, 'would that it was more common among pitmen. ${ }^{159}$

Coalminers faced regular accusations of fecklessness such as this, but the popularity of friendly societies in the coalfields - in spite of the reluctance of some to admit miners - shows that the ideal of independence was taken to heart by many. ${ }^{160}$ Like other welfare claimants, miners faced suspicion of fraud. To guard against this, welfare schemes - from the Poor Law to workplace sick clubs and friendly societies - put in place mechanisms to screen applicants. These mechanisms increasingly came to rely on medical surveillance as the period progressed. ${ }^{161}$ Yet it should also be remembered that suspicion went both ways and there were many reports of coalminers 
distrusting the motives of welfare providers. The reluctance of Durham miners in the early nineteenth century to accept a system of accident provision that might make them ineligible for poor relief shows how miners were reluctant to subscribe to any scheme that threatened what they saw as a right to relief from parochial sources. ${ }^{162}$ While employer paternalism in the form of medical care and sick pay played a significant role, attempts to expand this provision were seen by some as an attempt to exert greater control over workers, especially as trade unionism developed. ${ }^{163}$ The success of the permanent relief fund movement showed the value of co-operation between workers and employers in providing viable long-term assistance to disabled miners, but not every miner welcomed it. While the movement spread across the English coalfields in the 1860 s and 1870s, in south Wales it faced greater opposition, coming up against (in the view of George Campbell, secretary of the Lancashire and Cheshire Permanent Relief Society) the 'prejudices of miners against anything new'. ${ }^{164}$

Whereas the Poor Law and voluntary welfare provided by friendly societies were both important in addressing the problem of work-related incapacity, their approaches were different. Although inability to work was central to the notions of entitlement that animated the support mechanisms they administered, there were significant differences regarding how officials approached the question of incapacity. For friendly societies, the cause of a claimant's 'disability' or sickness was as important as its presence. This was less so in the context of the Poor Law. Friendly society rules often made moral considerations about inappropriate, and therefore ineligible, causes of incapacity. This meant it was possible for two miners with identical impairments and levels of incapacity to apply to a society for benefits and be treated in radically different ways depending on the causes of their injuries. Moreover, by prohibiting benefit recipients from working, many friendly societies effectively forced disabled miners to act out a 'sick role', in which they had to forgo certain ordinary social activities. In contrast, in Poor Law contexts, paupers could be recognised as sick, but still forced to work to some extent if they were capable of doing so. When it came to public welfare, enforcing the work ethic was paramount and idleness, for all but the totally incapacitated, was frowned upon. ${ }^{165}$

Friendly societies reinforced cultural ideals of working-class self-reliance, but in placing time restrictions on benefits, their funds were geared towards assisting with short-term sickness or incapacity. The permanent relief fund established in Northumberland and Durham in 1862 provided welfare on a different basis, allowing a more generous settlement for men left incapable of labour than that allocated to victims of 'minor accidents'. Whereas in other welfare contexts the term 'disability' was often used in loose ways, to refer to temporary as well as long-term incapacity, the permanent relief fund used 
'disablement' to refer to life-changing events that affected a person's livelihood in decisive and 'permanent' ways. Its emergence therefore represented an important moment in the history of disability and welfare, recognising that those with long-term conditions needed distinctive forms of relief that were not bound by temporal limitations.

The financial cost of mining accidents was considerable. But the impact of disablement was more than simply medical or financial - it also affected the standing of miners in their communities and relations within their families. The following chapter turns its attention to the question of how social relations in coalfield communities were affected by disability.

\section{Notes}

1 The Times, 30 December 1865. Our emphasis.

2 'The Miners' Relief', Glasgow Herald, 20 March 1878.

3 John Benson, 'The Thrift of English Coal-Miners 1860-95', Economic History Review, 31:3 (1978), 410-18; John Benson, 'English Coal-Miners' Trade-Union Accident Funds, 1850-1900', Economic History Review, 28:3 (1975), 401-12; John Benson, 'Coalowners, Coalminers and Compulsion: Pit Clubs in England 1860-80', Business History, 44:1 (2002), 47-60; John Benson, British Coalminers in the Nineteenth Century: A Social History (Dublin: Gill and Macmillan, 1980), ch. 7.

4 Deborah A. Stone, The Disabled State (London: Macmillan, 1985).

5 John Benson, 'Coalminers, Coalowners and Collaboration: the Miners' Permanent Relief Fund Movement in England, 1860-1875', Labour History Review, 68:2 (2003), 181-94.

6 PP 1842 (381), Appendix to the First Report of the Commissioners. Mines. Part 1. Reports and Evidence from the Sub-Commissioners, 460.

7 Norman McCord, 'Aspects of the Relief of Poverty in Early 19th-Century Britain', in R. M. Hartwell et al. (eds), The Long Debate on Poverty: Eight Essays on Industrialisation and 'the Condition of England' (London: Institute of Economic Affairs, 1972), 94-5; M. A. Crowther, 'Family Responsibility and State Responsibility in Britain before the Welfare State', The Historical Journal, 25 (1982): 131-45.

8 Jules Ginswick (ed.), Labour and the Poor in England and Wales 1849-1851: the Letters to the Morning Chronicle from the Correspondents in the Manufacturing and Mining Districts, the Towns of Liverpool and Birmingham, and the Rural Districts, vol. 2: Northumberland and Durham, Staffordshire, The Midlands (London: Frank Cass, 1983), 63.

9 Angela V. John, By the Sweat of their Brow: Women Workers at Victorian Coal Mines (London: Routledge and Kegan Paul, 1984), 24; Robert Duncan, The Mineworkers (Edinburgh: Birlinn, 2005), 35, 70. 
10 Roy Church, The History of the British Coal Industry, vol. 3: 1830-1913: Victorian Pre-Eminence (Oxford: Clarendon Press, 1986), 191.

11 PP 1842 (008), Sanitary Enquiry Scotland: Reports on the Sanitary Condition of the Labouring Population in Scotland, in Consequence of an Inquiry Directed to be Made by the Poor Law Commissioners, 85 and 94.

12 PP 1842 (380), Commission for Inquiring into the Employment and Condition of Children in Mines and Manufactories. First Report of the Commissioners, 19; PP 1842 (381), Appendix to First Report of the Commissioners, Part 1, 475.

13 PP $1842(381), 621$.

14 Ibid., 402.

15 Ibid., 452.

16 PP 1842 (381), 455.

17 PP 1842 (380), 19.

18 John, Sweat of Their Brow, 43; Duncan, The Mineworkers, 111.

195 \& 6 Victoria Cap. XCIX, An Act to Prohibit the Employment of Women and Girls in Mines and Collieries, to Regulate the Employment of Boys, and to Make Other Provisions Relating to Persons Working Therein, 10 August 1842.

20 John, Sweat of their Brow, 53.

21 Hansard, HC Deb, 16 May 1843, vol. 69, cols 475-6.

22 Although this support was threatened during industrial unrest, as we shall see in Chapter 5.

23 Benson, 'English Coal-Miners' Trade-Union Accident Funds', 402; M. J. Daunton, 'Miners' Houses: South Wales and the Great Northern Coalfield, 1880-1914', International Review of Social History, 25:2 (1980), 143-75.

24 Edward Rymer, The Martyrdom of the Mine (Middlesbrough, 1898), 5; Steven King, and Geoffrey Timmins, Making Sense of the Industrial Revolution: English Economy and Society, 1700-1850 (Manchester: Manchester University Press, 2001), 297. For more on gleaning at this time, see Peter King, 'Gleaners, Farmers and the Failure of Legal Sanctions in England 1750-1850', Past \& Present, 125 (1989), 116-50.

25 Andrew Walker, "'Pleasurable homes"? Victorian Model Miners' Wives and the Family Wage in a South Yorkshire Colliery District', Women's History Review, 6 (1997), 317-36.

26 Aberdare Times, 14 May 1864.

27 Merthyr Telegraph, 23 December 1865.

28 The Cambrian, 27 September 1878.

29 TNA, MH12/3052, Easington Union Poor Law Correspondence, Letter from the District Poor Law Commission Representative, 13 November 1840.

30 PP 1842 (008), 101.

31 Aberdare Times, 11 December 1886.

32 PP 1842 (381), 153.

33 PP 1842 (382), 553.

34 Northumberland Record Office, 263/A1/1, The Committee of Coal Owners 
of the Rivers Tyne and Wear, Committee Minute Books, 1805-15, Letter from William Putter to John Buddle, 3 June 1812.

35 Daniel Defoe, Essays upon Several Subjects: Or Effectual Ways of Advancing the Interests of the Nation (London: Thomas Ballard, 1702), 125.

36 See for instance Statistical Compendium, table 5.5, Govan Colliery Journals, Payments made to disabled miners, 1852-55, http://doi.org/10.5281/ zenodo.183686, accessed 24 March 2017.

37 C. G. Hanson, 'Craft Unions, Welfare Benefits, and the Case for Trade Union Law Reform, 1867-75', Economic History Review, 28 (1975), 244.

38 PP 1842 (381), 723.

39 Glamorgan Archives, P62/31, Llantrissant Parish Overseers Accounts, 1825-37, $142-3,152,161-2,172,181$. The name 'Richard Thomas' of Tonyrefail appears over the next five years, but it is not possible to ascertain whether this is the same person.

40 PP 1842 (381), 718.

41 PP 1844 (531), Report from the Select Committee on Medical Poor Relief, 270.

42 The literature on the old and new Poor Law is voluminous. See S. G. Checkland and E. O. A. Checkland (eds), The Poor Law Report of 1834. (Harmondsworth: Penguin Books, 1974); Anne Digby, The Poor Law in Nineteenth-Century England and Wales (London: Historical Association, 1982); Derek Fraser (ed.), The New Poor Law in the Nineteenth Century (London: MacMillan, 1976); J. D. Marshall, The Old Poor Law, 1795-1834, 2nd edn (Basingstoke: Macmillan, 1985); John Knott, Popular Opposition to the 1834 Poor Law (London and Sydney: Croom Helm, 1986); Steven King, Poverty and Welfare in England 1700-1850: A Regional Perspective (Manchester: Manchester University Press, 2000); Steven King, "'Stop This Overwhelming Torment of Destiny": Negotiating Financial Aid at Times of Sickness under the English Old Poor Law, 1800-1840', Bulletin of the History of Medicine, 79:2 (2005), 228-60.

43 See, for instance, TNA, MH2/1 Poor Law Commission: Rough and Classified Minute Books, 23 August to 31 December 1834; PP 1836 (595), 'Second Annual Report of the Poor Law Commissioners for England and Wales', Appendix A, 80; Gwent Archives, CSWBGP/M1, Pontypool Union Board of Guardians Minutes, 8 December 1838, 363.

44 TNA, MH12/3052, Easington Union Board of Guardians to Poor Law Commission (PLC), 14 October 1834 (received 16 October 1834).

45 Anne Borsay, Disability and Social Policy in Britain Since 1750: A History of Exclusion (Basingstoke: Palgrave Macmillan, 2005), 25-36; Iain Hutchison, A History of Disability in Nineteenth-Century Scotland (Lewiston, NY: Edwin Mellen Press, 2007), 131-70; David Ashforth, 'The Urban Poor Law', in Fraser (ed.), The New Poor Law, 135.

46 Fraser, 'Introduction', 18 (Table II); Kim Price, 'The Crusade Against OutRelief: A Nudge from History', The Lancet, 377:9770 (19 March 2011), 988-99; Elizabeth T. Hurren, Protesting about Pauperism: Poverty, Politics and Poor 
Relief in Late-Victorian England, 1870-1900 (London: Royal Historical Society, 2007).

47 PP 1871 [C.396], Twenty-Third Annual Report of the Poor Law Board, 357, 358, $377,378$.

48 Digby, The Poor Law, 8. For an early example from a Welsh mining community, see Glamorgan Archives, P62/5, Llantrisant parish: Vestry minute book, 1802$15,444$.

49 PP 1842 (381), 506.

50 PP 1866 (431), (431-I), 'Index to the Report from the Select Committee on Mines', 117; Digby, The Poor Law, 32; PP 1842 (381), 506.

51 PP 1842 (008), 102, 114.

52 Ibid.; The Statistical Accounts of Scotland 1791-1845: Blantyre, County of Lanark, Account of 1791-99, 220, http://stat-acc-scot.edina.ac.uk/link/179199/Lanark/Blantyre/2/220/, accessed 27 September 2016.

53 Hutchison, A History of Disability, 26-9.

54 Mitchell Library, Glasgow City Archives, CO1 27 97, Parish of Carluke, Record of Application for Relief 1866-77, no. 749, application for relief by Hugh McKay, 18 November 1869.

55 Scottish Poor Law Magazine, Vol. 5 (1871-72), 519.

56 Ibid., 106. Our emphasis.

57 'An Essay on the Poor Law of Scotland', Scottish Poor Law Magazine, 4 (187071), 139-40.

58 Hutchison, A History of Disability, 284, 185, 190.

59 Audrey Paterson, 'The Poor Law in Nineteenth-Century Scotland', in Fraser (ed.), The New Poor Law, 190.

60 The Poor Law Magazine for Scotland, 3 (1860-61), 148.

61 North Lanarkshire Archives CO1/37/56, 1870-75, no. 2, Applications for Relief, Dalziel, CO1 37 56, Application for relief from Thomas Campbell. For other cases see ibid, no. 79, John Bryson and no. 80, David Brennan.

62 See, for example, North Lanarkshire Archives, CO1 50 22, New Monklands Parochial Board, Letter Book, 1847-49, case of William Craig, 15 May 1849 (miner given meat and clothes during time spent out of work due to illness); Mitchell Library, Glasgow City Archives, C01 22 44, no. 124, Blantyre Parochial Board, Register of Poor, 1845-64, Alexander McCormick (paid for admission to Glasgow Infirmary).

63 Mitchell Library, Glasgow City Archives, C01 2790 no. 4, Parish of Carluke, Record of Application for Relief, James Watson, 18 July 1856.

64 Ibid., C01 2790 no. 141, Parish of Carluke, Record of Application for Relief, James Fyfe, 12 May 1858.

65 Ibid., CO1 2790 no. 88, Parish of Carluke, Record of Application for Relief, George Moffat, 10 June 1857.

66 Sharon N. Barnartt, 'Disability as a Fluid State: Introduction' in Sharon N. Barnartt (ed.), Disability as a Fluid State (Bingley: Emerald, 2010), 1-22. 
67 Mitchell Library, Glasgow City Archives, CO1 27 90, no. 194, Record of Application for Relief, Thomas Kerr, 10 December 1859; CO 2790 no. 199, Record of Application for Relief, John McKendrick, 27 December 1857.

68 Ibid., CO 2790 no. 329, Record of Application for Relief, Samuel Donaldson, 31 March 1862.

69 S. A. King, 'Constructing the Disabled Child in England, 1800-1860', Family and Community History, 18 (2015), 104-21.

70 John Benson, 'Poor Law Guardians, Coalminers, and Friendly Societies in Northern England, 1860-1894: Statutory Provision, Local Autonomy, and Individual Responsibility', Northern History, 44:2 (2007), 164.

71 Glamorgan Archives, P62/28, Llantrissant Parish Vestry minutes, Overseers' and Churchwarden's Accounts, 1813-25, 319.

72 Benson, 'Poor Law Guardians', 161, 164.

73 Ibid., 160-1; Benson, British Coalminers, 175.

74 McCord, 'Relief of Poverty', 95. Eric Hopkins, Working Class Self-Help in Nineteenth-Century England: Responses to Industrialisation (London: UCL Press, 1995).

75 Benson, 'Thrift', 412.

76 George L. Campbell, Miners' Insurance Funds, their Origin and Extent (London: Waterlow and Sons, 1880), 8; Merthyr Telegraph, 4 April 1857.

77 Colliery Guardian and Journal of the Coal and Iron Trades, 27 September 1878, 497.

78 The Times, 26 May 1880, 14.

79 Anon. [Samuel Smiles], 'Workmen's Benefit Societies', Quarterly Review, 116:232 (October 1864), 318.

80 PP 1873 [C.842], Third Report of the Commissioners Appointed to Inquire into Friendly and Benefit Societies; Together with Minutes of Evidence, Appendix and Index, 170, 175.

81 Benson, 'Thrift'.

82 Hopkins, Working-Class Self-Help, 9, 12.

83 James C. Riley, 'Disease Without Death: New Sources for a History of Sickness', Journal of Interdisciplinary History 17:3 (1987), 554.

84 Martin Gorsky, 'The Growth and Distribution of English Friendly Societies in the Early Nineteenth Century', Economic History Review 51:3 (1998), 493-4; Dot Jones, 'Did Friendly Societies Matter? A Study of Friendly Society Membership in Glamorgan, 1794-1910', Welsh History Review, 12:3 (1985), 324-49.

85 PP 1834 (44), Report from His Majesty's Commissioners for Inquiring into the Administration and Practical Operation of the Poor Laws, 887.

86 Hopkins, Working-Class Self-Help, 46; Benson, British Coalminers, 184.

87 Edmund Stonelake, The Autobiography of Edmund Stonelake, ed. A. Mór-O’Brien (Bridgend: D. Brown and Sons, 1981), 55, 57, 58.

88 Hopkins, Working-Class Self-Help, 3.

89 For example, National Archives of Scotland FS4/124, St Aloysius Friendly 
Society and Funeral Society, Chapelhall, Lanarkshire, 1863; ibid., FS4/101, Patna Loyal Orange Permanent Friendly Society, No. 103 Ayr, 1872-83.

90 Gwent Archives, D32.149, Rules of a Friendly Society of Tradesmen and others, called The Star Friendly Society, held at the Three Cranes, in the town of Pontypool, Monmouthshire (1831), rule 4. For later examples from other coalfields, see PP 1874 [C.961], [C.961-I], Fourth Report of the Commissioners Appointed to Inquire into Friendly and Benefit Building Societies. Part I. Report of the Commissioners, with Appendix, 181; Leslie A. Falk, 'Coal Miners' Prepaid Medical Care in the United States - and Some British Relationships, 1792-1964', Medical Care, vol. 4 (January-March 1966), 38.

91 TNA, FS2/3 Friendly Societies Indexes to Rules and Amendments, Series 1, no. 250, Beamish Colliery Friendly Society, 29 September 1835 to 5 September 1843; FS2/6 no. 57 United Colliers and Miners' Society, established 29 December 1831; National Archives of Scotland, FS1/16/20, Regulations of the Carfin Colliery Friendly Society, Instituted 12 October 1839.

92 TNA FS1/120 (Durham) no. 235, Rickleton and Harraton Outside Collieries' Relief Fund, certified 23 September 1833; Benson, British Coalminers, 179-81; Hopkins, Working-Class Self-Help, 44; P. H. J. H. Gosden, The Friendly Societies in England 1815-1875 (Manchester: Manchester University Press, 1961), 86.

93 Steve King, "'It is Impossible for our Vestry to Judge his Case into Perfection from Here:" Managing the Distance Dimensions of Poor Relief, 1800-40', Rural History, 16:2 (2005), 161-89.

94 Simon Cordery, British Friendly Societies, 1750-1914 (Basingstoke: Palgrave Macmillan, 2003), 26.

95 PP 1847-48 (648), Provident Associations Fraud Prevention Bill. Report from the Select Committee of the House of Lords ... Together with the Minutes of Evidence and Appendix, 62

96 Frederick Morton Eden, Observations on Friendly Societies, for the Maintenance of the Industrious Classes, during Sickness, Infirmity, Old Age, and Other Exigencies (London: J. White and J. White, 1801), 19-21.

97 Gwent Archives, Q.FSR.24-11, Rules and Orders of the United Colliers and Miners Society, meeting at the Clarence Inn[,] Trosnant, near Pontypool, established 4 September 1828, article 15; Swansea University, South Wales Coalfield Collection [hereafter SWCC], MNA/NUM/1/34/161, Glais Friendly Society, Rules and Articles, 1809, rule 42.

98 Hopkins, Working-Class Self-Help, 28-9.

99 James C. Riley, Sick, Not Dead: The Health of British Workingmen during the Mortality Decline (Baltimore: Johns Hopkins University Press, 1997).

100 Colliery Guardian, 12 September 1863, 204. For further evidence of the presence of the affiliated orders in mining settlements, see TNA, FS 2: Friendly Societies Indexes to Rules and Amendments, Series I, particularly FS2/3, FS2/8 and FS $2 / 13$.

101 PP 1852-53 (955), Friendly Societies. Return to an Order of the Honourable 
House of Commons, Dated 23 August 1852; for Copy of a Report and Tables ... on the Subject of Sickness Among the Members of Friendly Societies, as Shown by the Quinquennial Returns, to the 31st Day of December 1850, xxvi. For examples of age restrictions, see TNA FS1/120 (Durham) no. 231, Hetton Colliery Agents and Workmen's Friendly Society, certified 10 April 1832, rule 3; Swansea University SWCC, MNA/NUM/1/34/161, Glais Friendly Society, Rules and Articles, 1809, rule 23; Gwent Archives, Articles of the New Union Society, held at the Cross Keys [Inn] Pontypool, Monmouthshire, 1815, article 3. Benson, 'Coalowners, Coalminers and Compulsion', 55.

102 PP 1849 (458), Report from the Select Committee on the Friendly Societies Bill, 69; see also PP 1861 (464), Friendly Societies. Report of the Registrar of Friendly Societies in England, Appendix, 56.

103 Glamorgan Archives, DODD/6/2 Independent Order of Oddfellows: Bute Lodge (Llantrissant) Minute Book 1869-77, Lodge Meetings 11 October 1873, 8 November 1873.

104 PP 1872 [C.514], [C514-I], [C.514-II], Second Report of the Commissioners Appointed to Inquire into Friendly and Benefit Building Societies, Part 1, 59.

105 F. G. P. Neison, 'The Influence of Occupation on Health', The Foresters' Miscellany, April 1874, 81.

106 David Tonks, 'A Kind of Life Insurance: the Coal-Miners of North-East England 1860-1920', Family and Community History, 2:1 (1999), 48-9.

107 Cordery, British Friendly Societies, 26; Hopkins, Working-Class Self-Help, 18-20.

108 For example, National Archives of Scotland, FS1/16/29 Carfin Colliery Friendly Society, 1839; Gwent Archives, Q.FSR.14-13, Rules and Orders to be Observed by a Friendly Society of Tradesmen and Others called the Sons of the Globe in Pontypool, Commencing 21 March 1817, article xiii.

109 National Archives of Scotland, FS1/2/41 Kilmarnock Coal Cutters Society, 1834, article 2 .

110 Gwent Archives, Q.FSR.14-13, Rules and Orders to be Observed by a Friendly Society of Tradesmen and Others called the Sons of the Globe in Pontypool, Commencing 21 March 1817, articles vii, xxvi, xxviii.

111 Gwent Archives, Q.FSR.16-4 Rules and Orders of a Friendly Society of Tradesmen, Coal Miners and Others, article 6.

112 PP 1842 (381), 513.

113 Deborah Stone, The Disabled State (Philadelphia, PA: Temple University Press, 1984), 99-103.

114 National Archives of Scotland FS4/1102, Rules of the Tranent Miners New Friendly Society, Tranent, Haddingtonshire, 20 October 1873, clause xxxv.

115 Swansea University SWCC, MNA/NUM/1/34/159, Glais Friendly Society Correspondence re Sick Benefit Claims, 1814-77, Folder 3, 1840-46, Letter 2, 22 June 1844.

116 Ibid., Folder 13, 1857, letter 12, n.d.

117 Martin Gorsky, 'Friendly Society Health Insurance in Nineteenth-Century 
England' in Martin Gorsky and Sally Sheard (eds), Financing Medicine: the British Experience Since 1750 (London: Routledge, 2006), 154-7; TNA FS1/120 (Durham) Friendly Societies Index to Rules and Amendments, no. 240, Hebburn Colliery Relief Fund, certified 15 February 1837, rule 17.

118 Gosden, The Friendly Societies, 138-40; Riley, Sick, Not Dead, 10 and ch. 4.

119 Gwent Archives, Q.FSR.14-1, Rules of the Loyal General Picton Friendly Society, Founded 12 August 1817, rule 13; ibid, Q.FSR.16-8, Monydduslywyn [sic] Monmouthshire, Rules and Orders to be Observed by a Society of Tradesmen ... Called the Faithful Britons, Commencing October 31818 rule 30.

120 Riley, Sick Not Dead, 50; 'The Sick Chamber', The Foresters' Monthly Miscellany, vii, April 1848, 161-2.

121 National Archives of Scotland, FS4/1228 Rules of the Wishaw Iron Works, Miners' Annual Friendly Society, 1874, article xvi.

122 Riley, Sick, Not Dead, 18, 37, 101.

123 Gwent Archives, Q.FSR.13-14 Rules of a Friendly Society Held at the House of Edward Duffield in the Parish of Risca (Founded 11 May 1805), 14 July 1817, rules $12,17$.

124 Gwent Archives, D2174.262, The 'Sons of the Globe' ... Treasurer's Account Book, 1818-68, Disbursements 1820/1.

125 Jules Ginswick (ed.), Labour and the Poor in England and Wales 1849-1851: the Letters to the Morning Chronicle from the Correspondents in the Manufacturing and Mining Districts, the Towns of Liverpool and Birmingham, and the Rural Districts, vol. 3: South Wales-North Wales (London: Frank Cass, 1981), 85.

126 National Archives of Scotland, FS1/16/29, Regulations of the Carfin Colliery Friendly Society, Instituted 12 October 1839.

127 Ginswick (ed.), Labour and the Poor ... Vol. 3, 56.

128 PP 1873 [C.842], 131.

129 For example, Rickleton and Harraton Outside Collieries' Relief Fund, Rule 5.

130 PP 1842 (008), 85, 102; Riley, Sick, Not Dead, 17.

131 See, for example, the rules of the Carron Friendly Society: PP 1874 [C.961], [C.961-I], Fourth Report of the Commissioners Appointed to Inquire into Friendly and Benefit Building Societies. Part I, 404-5.

132 Glamorgan Archives, DODD/6/1 Independent Order of Oddfellows: Bute Lodge (Llantrisant) minute books, lodge meeting 24 January 1857.

133 Benson, 'English Coal-Miners' Trade-Union Accident Funds'.

134 'Assuring Colliers' Lives', Paisley Herald and Renfrewshire Advertiser, 10 July 1869.

135 The Miner and Workman's Advocate, no. 16, 20 June 1863, 4.

136 Campbell, Miners' Insurance Funds, 6, 8. Benson, 'Coalminers, Coalowners and Collaboration', 183.

137 'Miners' Permanent Relief Fund', The Newcastle Courant, 8 May 1863.

138 'Northumberland and Durham Miners' Permanent Relief Fund', The Newcastle Courant, 13 May 1864.

139 'The Miners' Permanent Relief Fund', The Newcastle Courant, 19 June 1868. 
140 PP 1873 [C.842], 126.

141 Ibid.

142 Ibid., 131.

143 'Proposed Miners' Permanent Relief Fund', The Glasgow Herald, 13 March 1878.

144 Campbell, Miners' Insurance Fund, 12.

145 Tyne and Wear Archives, CH.MPR/14/1 (MF2196), Miners' Permanent Relief Disablement Fund (1863-91).

146 'Miners' Permanent Relief Fund', The Newcastle Courant, 9 July 1880.

147 Tyne and Wear Archives, CH/MPR/1/1, Northumberland and Durham Miners' Permanent Relief Fund, committee minutes, 6 June 1863, 31 December 1864.

148 Tyne and Wear Archives, CH/MPR/5/6, Northumberland and Durham Miners' Permanent Relief Fund, Summary Report of the Sixteenth Annual Meeting, 13 July 1878.

149 'Northumberland and Durham Miners' Permanent Relief Fund', The Newcastle Courant, 13 May 1864.

150 'Miners' Permanent Relief Fund', The Newcastle Courant, 9 July 1880.

151 'The Cost of Colliery Accidents', The Times, 30 April 1879.

152 Benson, 'Coalminers, Coalowners and Cooperation', 187-91.

153 The British Miner and General Newsman, no. 2, 20 September 1862, 3; Miner and Workman's Advocate, no. 15, 13 June 1863, 5.

154 'Miners' Permanent Relief Fund', The Newcastle Courant, 16 May 1862.

155 British Miner and General Newsman, no. 8, 1 November 1862; ibid., no. 9, 8 November 1862, 3.

156 PP 1873 [C.842], 131.

157 Benson, 'Coalminers, Coalowners and Cooperation', 183.

158 Cordery, British Friendly Societies, 102.

159 Handel Cossham, 'Eminent Miners', lecture delivered to the Bristol Mining School, 3 March 1857 in Lectures Delivered at the Bristol Mining School, 1857 (Bristol: Bristol Mining School, 1857), 164-5.

160 Benson, 'Thrift'.

161 On the broader context, see Stone, Disabled State, 32; David M. Turner, "Fraudulent" disability in historical perspective', History and Policy (February 2012), http://www.historyandpolicy.org/papers/policy-paper-130.html, accessed 9 October 2016.

162 On the 'right' to relief, see Lorie Charlesworth, Welfare's Forgotten Past: a SocioLegal History of the Poor Law (Abington: Routledge, 2010).

163 Hopkins, Working-Class Self-Help, chs 4-6.

164 Campbell, Miners' Insurance Funds, 11.

165 Borsay, Disability and Social Policy, 22, 27, 32; Hutchison, A History of Disability, $275-6$. 